\title{
From fish and bushmeat to chicken nuggets: the nutrition transition in a continuum from rural to urban settings in the Colombian Amazon region
}

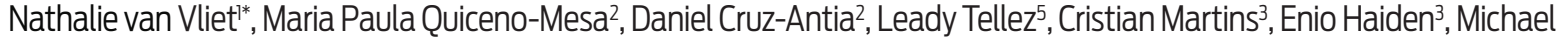 \\ Ribeiro de Oliveira ${ }^{3}$, Cristina Adams ${ }^{4}$, Carla Morsello ${ }^{4}$, Lorena Valencia ${ }^{5}$, Tamara Bonilla ${ }^{5}$, Blanca Yagüe ${ }^{5}$ and Robert Nasi'
}

\begin{abstract}
The current contribution of wild animal proteins has been poorly quantified, particularly in the rapidly growing urban centers of tropical forests. Lack of such evidence impairs food security strategies to include the diversity of food supply inherent to traditional food systems. In this study we focus on wild sources of animal protein: wild fish and bushmeat, which have traditionally been important in people's diets in the Amazon. We compare the consumption of wild and non-wild (domestic, processed) sources of animal proteins in a rural to urban gradient in the Colombian Amazon. In rural areas, most people are indigenous from the Ticuna ethnical group, while in urban areas, the population is a result of a mixture of different indigenous groups, mestizos and colonos. Our results show that, despite its geographical position, the region is increasingly dependent on domestic and industrialized sources of animal protein. The frequency of wild fish and bushmeat consumption decreases from rural to urban areas to the advantage of domestic and processed meat/fish. Patterns of animal protein consumption for indigenous children indicate that indigenous families adopt non-indigenous consumption patterns when they move to town. Bushmeat consumption in urban areas is more frequent in wealthier families and could be considered as a luxury product. In urban areas, chicken is the protein of the poor and beef replaces chicken for the families that can afford it. In rural settings, chicken replaces wild sources of animal protein as people increase their income and move away from forest/ agriculture dependent livelihoods. Despite, the low importance of bushmeat and wild fish in urban areas measured in terms of consumption frequencies, we show that these foods continue to play an important role in terms of dietary diversity, which is fundamental to eradicate energy and micronutrient deficiencies. The increased consumption of industrial chicken in rural communities poses important food security issues because it provides less nutritional balance than wild foods and access to this protein is dependent on the availability of cash in rural communities. While the harvest of wild proteins poses a sustainability problem, industrial foods also carry a heavy ecological footprint. In conclusion our results call for a better attention to the changes observed in diets in the Amazon, given their potential food security and ecological consequences.
\end{abstract}

1 Center for International Forestry Research, alan CIFOR Situ Gede, Sindang Barang Bogor (Barat) 16115. Indonesia.

* Corresponding author - E-mail adresses: vanvlietnathalie@yahoo.com

2 Fundación SI-Science International Calle 28 N¹3 A -24 oficina 308. Bogotá-Colombia.

3 Universidade Federal do Amazonas, Instituto Natureza e Cultura - campus Alto Solimões- Rua 1 de Maio Colônia Benjamin ConstantBrazil.

4 School of Arts, Science and Humanities, University of São Paulo.

5 Independent consultant. 


\section{INTRODUCTION}

Tropical forest resources are inextricably linked to people's food security, nutrition and health in a number of fundamental ways: forests provide a diversity of healthy foods, culturally valued products integral to local food systems and food sovereignty, and occasionally products that act as a 'safety net' or 'buffer' in times of shortages (see Wunder et al. 2014 for a broader discussion on the role of forests to overcome short crisis). Until the mid nineties, food consumption in tropical forests was still primarily related directly to the process of food acquisition and dominated by foraging strategies and subsistence cultivation. However, globalization, urbanisation and the expansion of market economies in the last decades are transforming dietary patterns throughout the world by replacing locally produced/harvested food with industrial and processed products (Popkin 2006; Popkin and Gordon-Larsen 2004). These changes in diet and activity patterns are commonly referred to as the "nutrition transition" (Popkin 2006). In tropical forest areas in general, the nutrition transition is characterised by a shift away from traditional foods (such as coarse grains, starchy roots and wild source of meat) toward staples (such as rice and wheat, increased fat, including animal fat from domestic and industrial sources of meat, and refined sugar consumption) (Drewnowski and Popkin 1997). The rapid rate of this transition and its impact on health in middleincome developing nations has drawn significant attention given the increased rates of intrinsically related chronic diseases (cancer, heart disease, stroke, diabetes, and osteoporosis) linked to the nutrition transition (Monteiro et al. 2007; Popkin 1994; Popkin et al. 2001). Because of the potential impacts on the increase of dietary and energy expenditure-related health problems such as obesity and high blood pressure, both commonly associated with cardiac diseases and type II diabetes (Silva and Padez 2010), the nutritional changes are important to assess, particularly in tropical forest areas where food from the forest or from small scale farming systems is replaced by industrialised products.
Nowadays, the majority of rural households in tropical regions, and a large proportion of urban households still rely on wild products to meet part of their food, nutritional, health and livelihood needs. In the rapidly growing urban centres of tropical forests, the contribution of these wild foods to people's diets is less known. Such evidence is crucial to include the diversity of the food supply inherent to indigenous and traditional food systems in food security strategies (Frison et al. 2011). At the same time, it is important to understand whether the use of wild products is sustainable from an ecological perspective, to avoid the "empty forests, empty stomachs" syndrome (Nasi et al. 2011). In recent years, world researchers have increased interest in describing the inextricable link between biodiversity and nutrition security (Johns and Eyzaguirre 2006; Burlingame et al. 2009; Kuhnlein et al. 2009; Bharucha and Pretty 2010). Several recent studies have analysed the contribution of wild sources of food in Africa (Jenkins et al. 2011; Cloete and Idsardi 2013; Sneyd et al. 2013), mostly focusing on edible plants (Termote et al. 2012; Weinberger and Swai 2006; Lutaladio et al. 2010) and on the links between wild foods and poverty (Ladio et al. 2013; Cloete and Idsardi 2013).

The Amazon tropical rainforest is one of these regions in which the nutrition transition is rapidly occurring. Previously, changes in food consumption patterns were costly, and only people in medium to high wealth levels were able to afford industrial food (Tagle 1988). A wide gap appeared between population groups who could afford more expensive, usually highly processed, foods and the poorer groups that maintained their traditional diets of mostly cereals, vegetables, roots, and grains (Bermudez and Tucket 2003). Currently, signs of nutrition transition are also commonly observed among the poorer households in remote rural forest areas (Benefice et al. 2007; Coimbra et al. 2002; Godoy et al. 2005a,b; Godoy et al. 2010; Gugelmin and Santos 2001; Lourenço et al. 2008; Piperata 2007; Silva et al. 2010; Tavares et al. 2003; Welch et al. 2009; Nardoto et al. 2011). With rurally focused research and village case studies increasing, we start to understand the changes observed in the consumption of wild products 
among rural people. However, we still need a better understanding of whether the consumption of wild food products persists or disappears in gradients from rural to growing urban areas (Stoian 2003).

In this study we focus on wild sources of animal protein: wild fish and bushmeat, which have traditionally been important in people's diets in the Amazon (Dufour 1991; DaSilveira and Thorbjarnarson 1999, Begossi et al. 1999, Silva and Begossi, 2009). In this research, we analyse consumption frequencies of wild fish and bushmeat as compared to domestic animal meat and processed animal products in a rural to urban gradient in the state of Amazonas, Colombia. The study is guided by the following research questions: 1 . Is there a significant difference in consumption frequencies, diversity and preferences of different sources of animal products from rural to urban areas? 2. Is the demise of wild sources of animal products a reality in rural and urban food intake, particularly for indigenous people? 3. What wild fish and bushmeat species are mostly consumed?; 4 . Is there a link between the consumption frequencies of wild animal products and ethnic background (indigenous/non-indigenous) or between consumption frequencies of wild animal products and income?

\section{MATERIAL AND METHODS}

\section{Study Site}

The study was carried out in 2012-2013 in the state of Amazonas, Colombia. The sampled sites comprised the town of $(37,832$ inhab.), a medium sized town (Puerto Nariño, 6,983 inhab), periurban communities close to Leticia (Kilometro 6, Kilometro 11 and Kilometro 18) and indigenous rural communities along the Amazon river (San Rafael, San Francisco, 20 de Julio, Macedonia, Nazareth, Mocagua and San Martín) (Fig. 1). While rural populations are exclusively indigenous, the urban population has resulted from different waves of migrants of indigenous (Ticuna, Yagua Cocama, Huitoto), colonos and mestizo origins from different countries (INEI 2010; Suárez-Mutis et al. 2010).

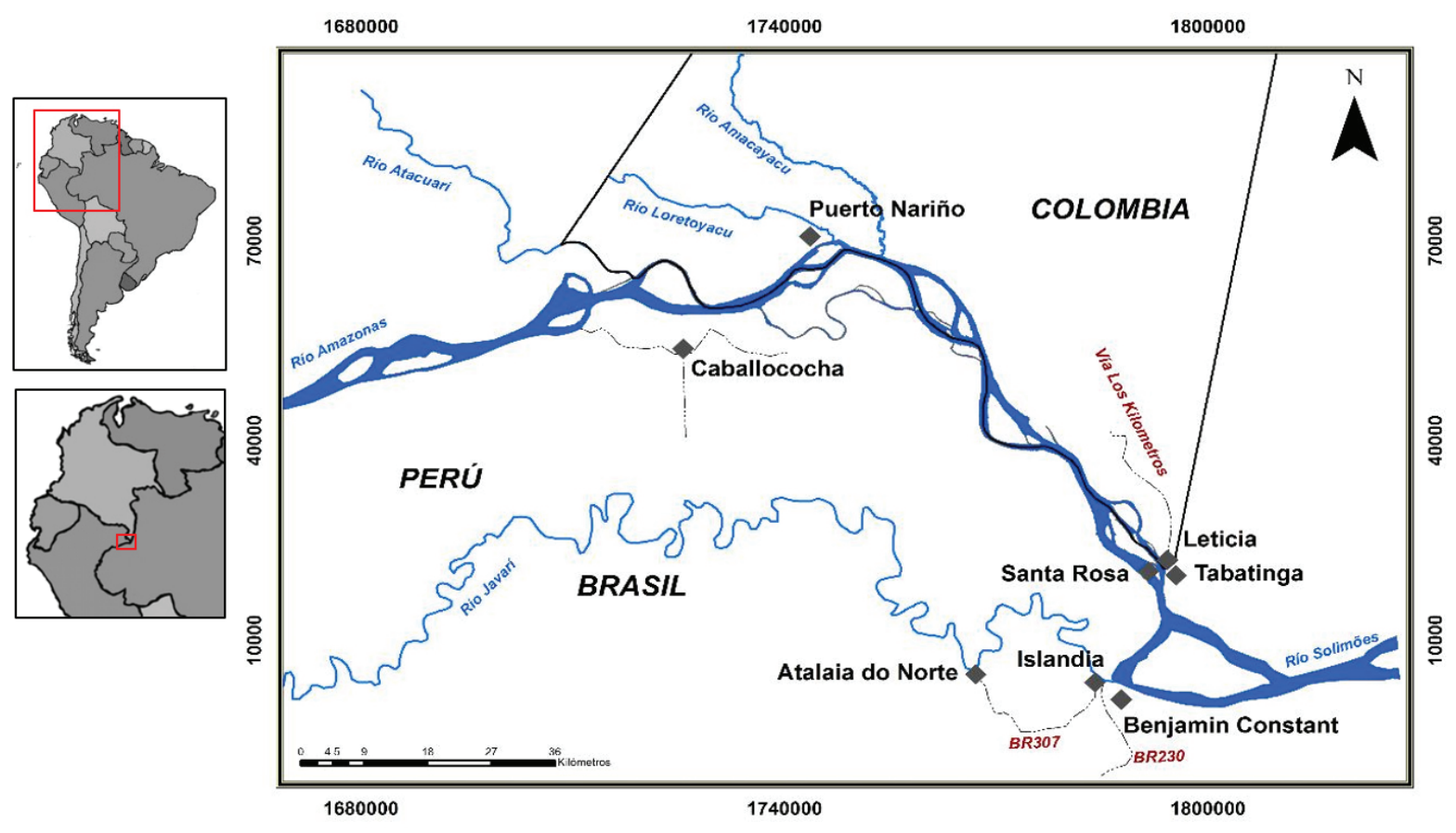

Figure 1. Map of the study area 


\section{Methods of data collection}

Our method of data collection follows van Vliet et al. (2014a) and is based on consumption surveys carried out with school children using a 24 hour recall method. This method is particularly suitable for rapid assessments, because it allows collecting data on numerous children, requires considerably less financial and human resources than household interviews, and has the potential to be used to monitor consumption over time at larger scales (van Vliet et al. 2014a). Permissions for working with children were obtained with the informed consent from competent authorities (school directors, teachers, parents), following the ethical research guidelines from the Center for International Forestry Research.

We assessed 1145 children from 11 schools ( 6 schools in Leticia (out of 11), 2 schools in Puerto Nariño (out of 2), 4 peri-urban school (out of 6), and 3 schools in rural indigenous communities), 491 children during low waters (September and October 2012) and 654 children from the same schools during high waters (April and May 2013) (Table 1). In both study periods we tried to interview the same children, but this was not always possible since we had to adapt to the availability of the class and the fact that class compositions change from one school year to the other. In rural areas, the small town of Puerto Nariño and peri-urban areas, we interviewed the only schools available (often one or two), whereas in Leticia (our urban site), our sample included schools that were geographically well distributed in town, including private and public schools, to account for the socio-economic diversity of the towns (6 out of the 11 schools were included in our sample). Our sample in rural areas was almost composed of only indigenous children because very few colonos or mestizos live in those communities. In urban areas instead, indigenous children only represented $15 \%$ of the sample (the others were either mestizos or colonos). In our sample of schools, we chose classes where children were between 12 to 16 years old to ensure that they were able understand the questions asked and recall the composition of their meals. When a school had several classes corresponding to these criteria, we chose to work with those where the professors showed greatest interest in the research. All children from a class were assessed concurrently by distributing a simple written questionnaire during lectures, explaining each question one by one, and leaving some time between questions for the children to complete the questionnaire with the assistance from the teacher and the researchers. The fact that the questionnaire was completed as an assignment during lectures with their own teacher's presence ensured that children responded with more seriousness, and respected silence when completing the responses, thereby guarantying the independence of individual questionnaires. The researchers also checked the responses and asked questions to the interviewee if any doubt subsisted with a given response, therefore guarantying the quality of the responses collected and ensuring that no blanks were left.

Table 1. Number of children interviewed in each site (low waters and high waters seasons)

\begin{tabular}{l|c|c}
\hline & \multicolumn{2}{|c}{$\begin{array}{c}\text { Number of children } \\
\text { interviewed }\end{array}$} \\
\hline Location & $\begin{array}{c}\text { low waters } \\
\text { season }\end{array}$ & $\begin{array}{c}\text { high waters } \\
\text { season }\end{array}$ \\
\hline Leticia & 274 & 353 \\
\hline Puerto Narino & 94 & 166 \\
\hline $\begin{array}{l}\text { Peri urban areas of “los } \\
\text { Kilometros” }\end{array}$ & 63 & 59 \\
\hline $\begin{array}{l}\text { Indigenous } \\
\text { communities Subtotal }\end{array}$ & 60 & 76 \\
\hline \multicolumn{1}{c}{491} & 654 \\
\hline
\end{tabular}

For each of the meals consumed the day before the interview, children were asked if they had eaten any of the most common sources of animal products available: wild fish, bushmeat, pork, chicken, eggs, mouton, beef, duck, or canned meat/fish. Here we use the definition of bushmeat from the Convention on Biological Diversity Bushmeat Liaison Group, which defines bushmeat (or wild meat) as wild animals (including mammals, amphibians, insects, reptiles, birds but excluding fish or aquatic molluscs) hunted or harvested in tropical and sub-tropical countries for food and for non-food purposes, including medicinal use (CBD 2011). If they had consumed bushmeat or wild fish, we asked about the names of the species consumed. 
Children were asked to name their most preferred animal proteins. We also complemented our questionnaire with information about the ethnical group (indigenous, colono or mestizo) and father's/ mother's profession/occupation. The profession/ occupation categories were used to infer an estimation of the qualitative and quantitative characteristics of income. Four categories were used: 1: low or no income: for retired persons, students, housekeepers or unemployed; 2. irregular non-forest/non-agricultural income for persons with temporary or unqualified job, small business holders or craftmen; 3 . irregular income from forest or agriculture: for farmer/hunter/ fishermen, 4. wage above the minimum salary for civil servants or other salaried job.

\section{Data analysis}

In a gradient from rural indigenous communities to the town of Leticia (including the small town and peri urban communities), we qualitatively compared: 1. the consumption frequencies of different sources of animal food (bushmeat and wild fish; domestic meats, processed meat/fish); 2 . the wild species consumed (wild fish and bushmeat species). and 3. the preferences for different types of animal food. We also analysed the diversity of animal food types consumed at those different sites, using the Shannon index of diversity, a quantitative measure that reflects richness taking into account how evenly the meals are distributed among those animal food sources. The index is based on the following formula (Equation 1) where $\mathrm{H}$ is the index of diversity and $\mathrm{pi}$ is the percentage of meals with animal sources of food:

$$
H=-\sum p_{i}^{*} \ln \left(p_{i}\right)
$$

Equation 1. Index of diversity used to assess the diversity of animal protein consumption

With $\mathrm{H}=$ index of diversity of sources of animal food and $\mathrm{pi}=$ frequency of children that consumed each source of animal food.
We computed a Discriminant Factor Analysis (Lambda Wilks test) computed on XIstat2014® to test the difference in animal protein consumption patterns between rural and urban areas. To account for ethnic differences, and based on the fact that rural children in our sample are all indigenous, we only took into account indigenous children for both rural and urban areas. This analysis allowed us to understand whether animal food consumptions patterns varied between indigenous living in their communities and indigenous families that have migrated to town. In addition, we also computed a Discriminant Factor Analysis (Lambda Wilks test) between low waters and high waters seasons for urban children. The one-way analysis of variance (ANOVA) and pair wise post hoc analysis was used to compare mean frequencies of animal protein consumption according to the main occupation of the father. The same was done to compare mean frequencies of animal protein consumption according to mother's occupation.

\section{RESULTS}

Our results show that less than $1 \%$ of the sampled children did not eat any type of animal food the day before the questionnaire (including children from indigenous communities, small town, peri-urban areas and town). As we move from rural indigenous communities to urban areas, we show a clear gradient characterized by an increased frequency of children having consumed poultry or eggs, beef and processed meat/ fish, and a decreased frequency of those having consumed wild fish and bushmeat (Fig. 2). In urban areas, only $2 \%$ of the children ate bushmeat the day before the questionnaire and $9 \%$ ate wild fish, whereas in rural communities the percentage of children having consumed bushmeat or wild fish was equal to $11 \%$ and $40 \%$ respectively. 


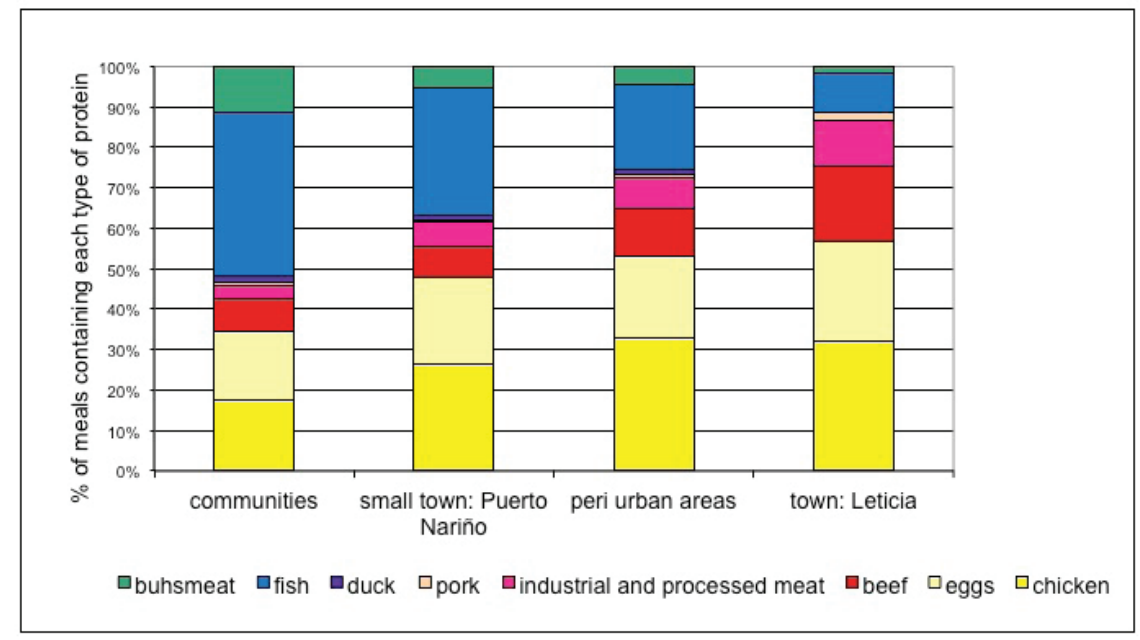

Figure 2. Percentage of meals containing each type of animal protein in rural communities along the river, the small town of Puerto Nariño, peri-urban areas and the major town of Leticia

The sources of animal protein consumed were twice as diversified in rural communities, small towns and peri-urban areas than in towns (indigenous rural communities: $\mathrm{H}=0.33$; small towns: $\mathrm{H}=0.37$; peri-urban areas: $\mathrm{H}=0.32$; urban areas: $H=0.14)$. The results of the Discriminant factor analysis on animal food consumption between indigenous children and non-indigenous children in urban areas show a non-significant difference between these two groups $(p=0,191)$. Indigenous children in urban areas ate significantly less bushmeat and wild fish $(p=0,001$ and $p<=0,001$ respectively) and significantly more chicken $(p<0,0001)$ and eggs $(p=0,006)$ than indigenous children from rural areas and consumption patterns of non-indigenous urban children matched those of indigenous urban children (Fig. 3).

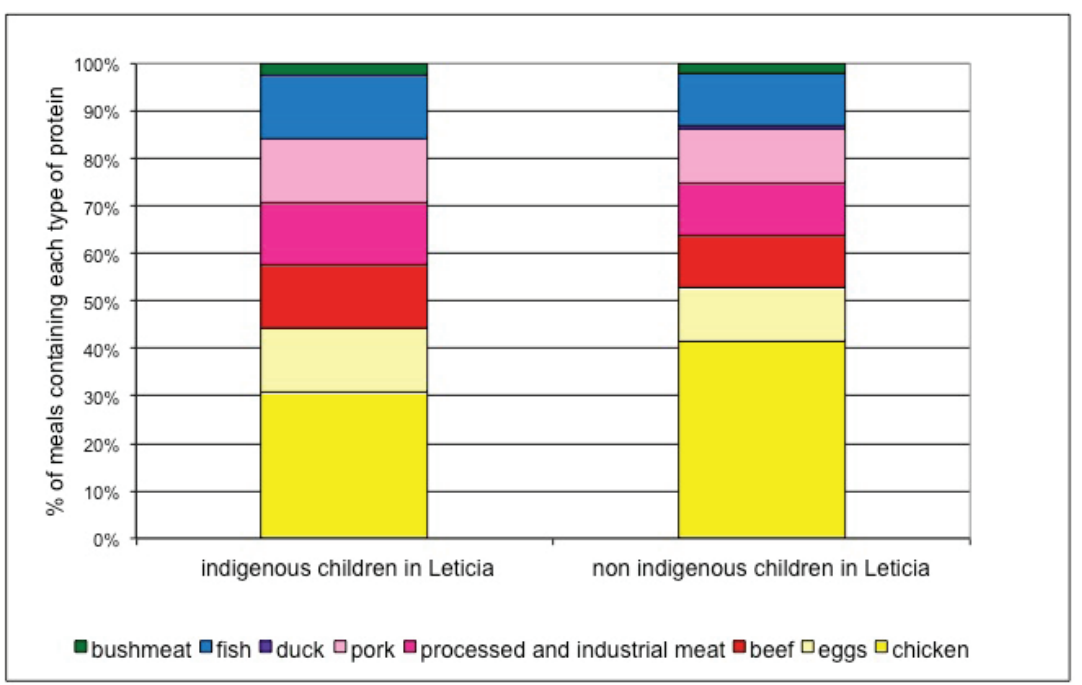

Figure 3. Percentage of meals containing each type of animal protein among indigenous and non indigenous children in Leticia 
There was no significant difference in animal food consumption patterns between the rainy and dry seasons $(p=0,08)$, except for bushmeat consumption $(p=0,008)$ (significantly more children ate bushmeat during the rainy season). The most consumed bushmeat species were paca (Cuniculus paca, $58 \%$ of the meals containing bushmeat) during the dry season and paca $(56 \%)$, deer (Mazama Americana, 22\%), tapir (Tapirus terrestris, $17 \%$ ) during the rainy season (Table 2). The most consumed fish species were palometa (Mylossoma duriventis, $34 \%$ of the meals containing fish) and surubí (Pseudoplatystoma fasciatum, 17\%) during the dry season and bocachico (Prochilodus sp., 43\%), palometa (Mylossoma duriventis, 21\%) and pintadillo (Pseudoplatystoma tigrinum, 14\%) during the rainy season.

All children from rural to urban areas stated a preference for beef and eggs (Fig. 4).

Table 2. List of bushmeat and fish species consumed during low waters and high waters

\begin{tabular}{|c|c|c|c|c|}
\hline & Common name & Scientific name & \begin{tabular}{|c|} 
Percentage of \\
meals with each \\
species during \\
the high waters \\
season \\
(N=1962) \\
\end{tabular} & $\begin{array}{c}\text { Percentage of } \\
\text { meals with } \\
\text { each species } \\
\text { during the low } \\
\text { waters season } \\
(\mathrm{N}=1473) \\
\end{array}$ \\
\hline \multirow{9}{*}{$\begin{array}{l}\text { Bushmeat } \\
\text { species }\end{array}$} & Tapir & Tapirus terrestris & $17 \%$ & $3 \%$ \\
\hline & Paca & Cuniculus paca & $56 \%$ & $58 \%$ \\
\hline & Peccari & Pecari tajacu, Tayassu pecari & $0 \%$ & $6 \%$ \\
\hline & Agouti & Dasyprocta fuliginosa & $6 \%$ & $6 \%$ \\
\hline & Deer & Mazama americana & $22 \%$ & $3 \%$ \\
\hline & Capybara & Hydrochoerus hydrochaeris & $0 \%$ & $6 \%$ \\
\hline & Caiman & Caiman crocodilus & $0 \%$ & $6 \%$ \\
\hline & Tortoises & Chelonoidis denticulata & $0 \%$ & $6 \%$ \\
\hline & Mojojoi (beetle larvae) & Rhynchophorus palmarum & $0 \%$ & $8 \%$ \\
\hline \multirow{14}{*}{ Fish species } & Palometa & Mylossoma duriventis & $22 \%$ & $33 \%$ \\
\hline & Pintadillo & Pseudoplatystoma tigrinum & $14 \%$ & $8 \%$ \\
\hline & Cucha & Hypostomus plecostomus & $2 \%$ & $0 \%$ \\
\hline & Bocachico & Prochilodus sp. & $43 \%$ & $0 \%$ \\
\hline & Arenga & Pellona castelnaeana & $0 \%$ & $8 \%$ \\
\hline & Surubí & Pseudoplatystoma fasciatum & $2 \%$ & $17 \%$ \\
\hline & \begin{tabular}{|l|} 
Yaguariche \\
\end{tabular} & Potamorhina latior & $2 \%$ & $0 \%$ \\
\hline & Carahuasú & Astronotus ocellatus & $2 \%$ & $0 \%$ \\
\hline & Paco & Piaractus brachypomus & $6 \%$ & $8 \%$ \\
\hline & Pirarucu & Arapaima gigas & $4 \%$ & $8 \%$ \\
\hline & Tucunare & Cichla sp. & $2 \%$ & $0 \%$ \\
\hline & Sábalo & Brycon melanopterus & $2 \%$ & $0 \%$ \\
\hline & Mota & Calophysus macropterus & $0 \%$ & $8 \%$ \\
\hline & Tambaqui & Colossoma macropomum & $0 \%$ & $8 \%$ \\
\hline
\end{tabular}

Among urban children, those whose father had a wage above minimum salary ate significantly less chicken (ANOVA, $p=0,04$ ), and more beef and bushmeat (but not significantly). Instead, mother's profession did not significantly explain consumption patterns. In rural communities, peri-urban areas and the small town of Puerto Nariño, children whose father had wage above minimum salary ate significantly more chicken (ANOVA, $p<0,0001$ ) and more eggs (ANOVA, $p=0,04$ ). Children whose father an irregular income from forest or agriculture ate significantly more fish (ANOVA, $p=0,0002$ ). There was no significant difference in consumption patterns of fish and bushmeat in relation to mother's profession. 


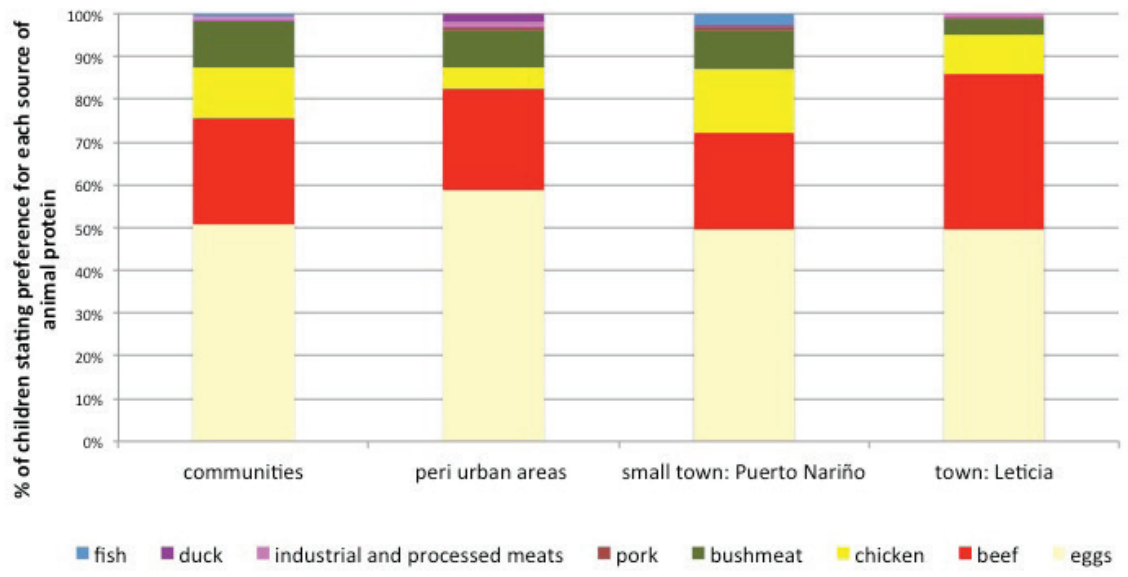

Figure 4. Percentage of children stating preference for each type of animal protein in rural communities, the small town of Puerto Nariño, peri-urban areas and the major town of Leticia

\section{DISCUSSION}

Our results show that, despite its geographical position along the Amazon river and in the middle of a large forest block, the region is increasingly dependent on domestic and industrialized sources of animal protein. In Leticia, we show that only $2 \%$ of the children ate bushmeat and $9 \%$ ate wild fish the day before the interview, whereas in rural communities the frequency reached $11 \%$ and $40 \%$ for bushmeat and wild fish respectively. Silva and Begossi (2009) also reported a lower consumption of wild foods in the urban area as compared to rural communities in the Brazilian Amazon, and, as also shown here, they evidenced higher bushmeat consumption during the high waters season and higher fish consumption during low waters. In comparison, in a study conducted in Madagascar, Jenkins et al. (2011) found wild fish and bushmeat consumption frequencies to reach $24 \%$ in urban areas and $12 \%$ in rural areas where the majority of the children did not eat any source of animal food at all. In our study site, less than $1 \%$ of the children did not eat any animal protein at all (as compared to $44 \%$ among urban kids in Democratic Republic of Congo, van Vliet et al. 2014a) and this is probably explained by the availability and low price of domestic and industrialized sources of animal protein characteristic of Latin America (Rushton et al. 2005).

Our results show a gradient in the frequency of wild fish and bushmeat consumption decreasing from rural to urban areas to the advantage of domestic and processed meat/fish. Indigenous children that live in urban areas eat significantly more chicken and eggs and less bushmeat and wild fish than indigenous children from rural communities. In fact, the patterns of animal protein consumption for indigenous children in urban areas match those from non-indigenous children, indicating that indigenous families adopt non-indigenous consumption patterns when they move to town. Similar patterns were observed in Alto Solimões (Nardoto et al. 2011) and in Ituqui Island in the Brazilian Amazon (Murrieta and Dufour 2004) where the typical diet is shifting away from bushmeat and fresh fish consumption to the dependency on frozen fish and industrial or mass processed foods. As suggested by Dounias and Froment (2011), diets are sensitive indicators of the ecological and cultural costs that indigenous people currently pay to achieve their share of modernity. Indeed, this transition translates in the increase of dietary and energy expenditure-related health problems such as obesity and high blood pressure, both commonly associated with cardiac 
diseases and type II diabetes (Silva and Padez 2010). As the urbanization process in the Amazon region seems to follow a complex pattern along a rural-urban gradient (Guedes et al. 2009; Padoch et al. 2008; WinklerPrins and de Souza 2005), the speed at which such change occurs might also result in a mixed pattern in which under- and over-nutrition might coexist, placing an additional burden on Amazonian people (Nardoto et al. 2011).

Our results show that bushmeat consumption in urban areas is more frequent in families where the household lives out of a wage above minimum salary (civil servants or qualified salaried jobs). Bushmeat is actually among the most expensive protein types in Leticia together with beef (van Vliet et al. 2014b) and could be considered as a luxury product. In urban areas, our results suggest that chicken is the protein of the poor and beef replaces chicken for the families that can afford it. In rural settings, fish is more frequently consumed among children whose household depends on forests/ agriculture and chicken is most often consumed by the wealthiest rural families (with a wage above minimum salary), suggesting that chicken replaces wild sources of animal protein in rural areas as people increase their income and move away from forest/agriculture dependent livelihoods. Some authors claim that as dependence on a market economy and external goods increases, subsistence-based production shifts toward consumption of processed foodstuffs (Padoch et al. 2008).

Despite, the low importance of bushmeat and wild fish in urban areas measured in terms of frequency of consumption, we show that these wild sources of animal food continue to play an important role in terms of dietary diversity. We found a higher diversity in animal proteins in the diets from rural children than those found in urban children, in particular because the later have a diet dominated by chicken and eggs. More over, in rural areas where wild sources of animal food are more frequently consumed, children have access to a variety of sources of meat from the wild (14 species of fish and 9 species of bushmeat mentioned in two 24 hours recall sessions). The contribution of wild foods to food intake diversity has also been demonstrated by Cloete and Idsardi (2013) in
South Africa, Termoto et al. (2012) in Democratic Republic of Congo and Sneyd (2013) in Cameroon. Several researchers consider that the promotion of biodiverse diets (diets with a high number of species) can be an effective and sustainable way to address the current dietary challenges by increasing the number of foods in the diet, and eradicating energy and micronutrient deficiencies (Burlingame et al. 2006; Flyman and Afolayan 2006; Johns and Eyzaguirre 2006; Englberger et al. 2010a; FAO 2010). Diversified diets have been shown to contribute to food security (Hoddinott and Yohannes 2002), to be adequate in nutrients (Ruel 2003; Torheim et al. 2004; Steyn et al. 2006; Kennedy et al. 2007), and to be associated with improved nutritional status (Arimond and Ruel 2004; Savy et al. 2005).

In ecological terms, the consequences of such nutrition transition is not necessarily straight forward. Conservation policies usually alienate local users from their natural resources pushing for the adoption of alternative foods (often from domestic and/or industrial origin) as a strategy to reduce unsustainable harvest. However, these alternative sources of animal protein come from industrial production systems from the South of Brazil (in the case of frozen chicken) with a high ecological footprint (including the fact that chicken are fed with industrially produced agricultural crops potentially pushing the Amazon deforestation frontier and the carbon footprint of transporting this product to remote areas in the Amazon). On the other hand, sustainable fishing and hunting is increasingly difficult to achieve with growing human populations, increased efficiency of fishing and hunting techniques and habitat destruction due to urbanization and infrastructure development, challenging the ecological sustainability of urban consumption of wild foods (Nasi et al. 2008). The potential impact of large-scale development projects or habitat change, such as deforestation and dams in rivers, on availability of wild foods in the Amazon Basin, also needs further consideration. For example, recent studies emphasize the impact of dams on fish and bushmeat species in the Amazon (Hallwass et al. 2013; Benchimol and Peres 2015). These major changes are in course in most of the 
Amazon Basin, so their potential influence on food security needs to be addressed.

In conclusion our results call for a better attention to the changes observed in the quality of protein intake in the Amazon, given it's potential consequences on health, nutrition and biodiversity conservation. We particularly emphasize the need for a better integration of biodiversity conservation, food security policies and development strategies. These sectors need to work in collaboration to ensure complementarity and reduce the inevitable trade-offs.

\section{ACKNOWLEDGEMENTS}

We are grateful to the children, their parents, the teachers and school directors who accepted to participate in this study. This research was funded by USAID and UKAID through the Bushmeat Research Initiative from CIFOR.

\section{REFERENCES}

1. Arimond M, Ruel MT (2004) Dietary diversity is associated with child nutritional status: evidence from 11 Demographic and Health Surveys. Journal of Nutrition 134(10):2579-2585.

2. Begossi A, Silvano RAM, Amaral BD, Oyakawa OT (1999) Use of local resources by fishers and hunters in an extractive reserve (Upper Juruâ, Acre, Brazil). Environmental Development and Sustainability 1:73-93.

3. Benchimol M, Peres CA (2015) Widespread Forest Vertebrate Extinctions Induced by a Mega Hydroelectric Dam in Lowland Amazonia. PLOS ONE 10(7): e0129818. doi:10.1371/journal. pone. 0129818

4. Benefice E, Lopez R, Monroy S, Rodríguez S (2007) Fatness and overweight in women and children from riverine Amerindian communities of the Beni River (Bolivian Amazon). American Journal of Human Biology 19(1):61-73.

5. Bermudez Ol, Tucket KL (2003) Trends in dietary patterns in Latin America. Cad Saúde Pública 19:S87-S99.

6. Bharucha Z, Pretty J (2010) The roles and values of wild foods in agricultural systems. Philosophical Transactions of the Royal Society B: Biological Sciences 365:2913-2926.

7. Burlingame $B$, Charrondiere R, Halwart M (2006) Basic human nutrition requirements and dietary diversity in rice-based aquatic ecosystems. Journal of Food Composition and Analysis 19 (6-7): 770 doi:10.1016/j.jfca.2006.03.009.

8. Burlingame B, Charrondiere R, Mouille B (2009) Food composition is fundamental to the cross-cutting initiative on biodiversity for food and nutrition. Journal of Food Composition and Analysis 22: $361-365$.
9. CBD (2011) Livelihood alternatives for the unsustainable use of bushmeat. Report prepared for the CBD Bushmeat Liaison Group. Technical Series No. 60, Montreal, SCBD.

10. Cloete PC, Idsardi EF (2013) Consumption of Indigenous and Traditional Food Crops: Perceptions and Realities from South Africa. Agroecology and Sustainable Food Systems doi: 10.1080/21683565.2013.805179

11. Coimbra CEAJr, Flowers NM, Salzano FM, Santos RV (2002) The Xavánte in transition: health, ecology and bioanthropology in Central Brazil. Ann Arbor, Ml: The University of Michigan Press.

12. Da Silveira R, Thorbjarnarson JB (1999) Conservation implications of commercial hunting of black and spectacled caiman in the Mamirauá Sustainable Development Reserve, Brazil. Biological Conservation 88: 103-109.

13. Dounias E, Froment $A$ (2011) From foraging to farming among present-day forest hunter-gatherers: consequences on diet and health. International Forestry Review 13(3): 338-354.

14. Drewnowski A, Popkin BM (1997) The nutrition transition: new trends in the global diet. Nutritional Review 55(2):31-43.

15. Dufour DL (1991) Diet and nutritional status of Amerindians: a review of the literature. Cadernos de Saúde Pública 7:481-502.

16. Eden MJ (1990) Ecology and land management in Amazonia. Belhaven Press, London, UK

17. Englberger L, Kuhnlein HV, Lorens A, Pedrus P, Albert K, Currie J, Pretrick M, Jim R, Kaufer L (2010a) Pohnpei, FSM case study in a global health project documents its local food resources and successfully promotes local food for health. Pacific Health Dialog 16(1):121-128.

18. FAO (2010) The state of food insecurity in the world: Addressing food insecurity in protracted crises. FAO, Rome.

19. Flyman MV, Afolayan AJ (2006) The suitability of wild vegetables for alleviating human dietary deficiencies. South African Journal of Botany 72(4):492-497.

20. Frison EA, Cherfas J, Hodgkin T (2011) Agricultural Biodiversity Is Essential for a Sustainable Improvement in Food and Nutrition Security. Sustainability 3:238-253.

21. Godoy R, Byron E, Reyes-García V, Vadez V, Leonard WR, Apaza L, Huanca T, Pérez E, Wilkie D (2005a) Income inequality and adult nutritional status: anthropometric evidence from a preindustrial society in the Bolivian Amazon. Social Science \& Medicine 61:907-919.

22. Godoy R, Reyes-García V, Vadez V, Leonard WR, Huanca T (2005b) Human capital, wealth, and nutrition in the Bolivian Amazon. Economics \& Human Biology 3:139-162.

23. Godoy R, Nyberg C, Eisenberg DT, Magvanjav 0, Shinnar E, Leonard WR, Gravlee C, Reyes-García V, McDade TW, Huanca T, Tanner S (2010) Short but catching up: statural growth among native Amazonian Bolivian childre. American Journal of Human Biology 22(3):336-347.

24. Gugelmin SA, Santos RV (2001) Ecología hhumana e antropometria nutricional de adultos Xavánte, Mato Grosso, Brasil. Cadernos de Saúde Pública 17:313-322.

25. Hallwass, G., P.F. Lopes, A.A. Juras, and R.A.M. Silvano. 2013. Fishers' knowledge identifies environmental changes and fish abundance trends in impounded tropical rivers. Ecological Applications 23: 392-407.

26. Hoddinott $J$, Yohannes $Y$ (2002) Dietary diversity as a food security indicator. FANTA Washington DC. [http://www.aed.org/ Health/upload/dietarydiversity.pdf] Accessed 01 February 2015 
27. INEI (2010) Perú: Análisis Etnosociodemográfico de las Comunidades Nativas de la Amazonía, 1993 y 2007. Dirección Técnica de Demografía e Indicadores Sociales - Fondo de población de las Naciones Unidas. Lima-Perú.

28. Jenkins RKB, Keane A, Rakotoarivelo AR, Rakotomboavonjy V, Randrianandrianina FH, Razafimanahaka HJ, Ralaiarimalala SR, Jones JPG (2011) Analysis of Patterns of Bushmeat Consumption Reveals Extensive Exploitation of Protected Species in Eastern Madagascar. PIoS ONE 6(12):e27570.

29. Johns T, Eyzaguirre PB (2006) Linking biodiversity, diet and health in policy and practice. Symposium on "wild冈gathered plants: basic nutrition, health and survival". Linking biodiversity, diet and health in policy and practice. Proceedings of the Nutrition Society 65: 182-189.

30. Kennedy G, Pedro MR, Seghieri C, Nantel G, Brouwer I (2007) Dietary diversity score is a useful indicator of micronutrient intake in non breast-feeding Filipino children. Journal of Nutrition 137:1-6.

31. Kuhnlein HV, Erasmus B, Spigelski D (2009) Indigenous Peoples' Food Systems: the Many Dimensions of Culture, Diversity and Environment for Nutrition and Health. Food and Agriculture Organization of the United Nations and Centre of Indigenous Peoples' Nutrition and Environment, Rome.

32. Ladio A, Richeri M, Beeskow A (2013) Conocimiento tradicional y autosuficiencia: la herbolaria rural en la Meseta Central del Chubut (Argentina). Boletin Latinoamericano y del Caribe de Plantas Medicinales y Aromáticas 12: 24-37.

33. Lourenço A, Santos R, Orellana J, Coimbra Jr C (2008) Nutrition transition in Amazonia: Obesity and socioeconomic change in the Surui Indians from Brazil. American Journal of Human Biology 20(5):564-571.

34. Lutaladio N, Burlingame B, Crews J (2010) Horticulture, biodiversity and nutrition. Journal of Food Composition and Analysis 23(6): 481-485.

35. Monteiro CA, Conde WL, Popkin BM (2007) Income-specific trends in obesity in Brazil: 1975-2003. American Journal of Public Health $97(10): 1808-1812$

36. Murrieta RSS, Dufour D (2004) Fish and farinha: protein and energy consumption in Amazonian rural communities on Ituqui Island, Brazil. Ecology of Food and Nutrition 43:231-255.

37. Nardoto G, Murrieta R, Prates L, Adams C, Garavello M, Schor T, Moraes A, Rinaldi F, Gragnami J, Moura E, Duarte-Neto P, Martinelli L (2011) Frozen chicken for wild fish: Nutrition transition in the Brazilian Amazon region determined by carbon and nitrogen stable isotope ratios in fingernails. American Journal of Human Biology 23(5):642-650.

38. Nasi R, Taber A, van Vliet N (2011) Empty forests, empty stomachs: bushmeat and livelihoods in Congo and Amazon Basins. International Forestry Review 13 (3):355-368

39. Padoch CE, Brondizio EC, Pinedo-Vasquez M, Sears RR, Siqueira A (2008) Urban forest and rural cities: multi-sited households, consumption patterns, and forest resources in Amazonia. Ecology and Society 13: 2. [online] URL: http://www.ecologyandsociety. org/vol13/iss2/art2/.

40. Piperata BA, Spence JE, Da-Gloria P, Hubbe M (2011) The nutrition transition in Amazonia: rapid economic change and its impact on growth and development in Ribeirinhos. American Journal of Physical Anthropology 146:1-13.

41. Piperata BA (2007) Nutritional status of Ribeirinhos in Brazil and the nutrition transition. American Journal of Physical Anthropology 133:868-878.
42. Popkin BM, Gordon-Larsen P (2004) The nutrition transition: worldwide obesity dynamics and their determinants. International Journal of Obesity 28: S2-S9.

43. Popkin BM, Horton S, Kim S (2001) The Nutrition Transition and Prevention of Diet-related Chronic Diseases in Asia an the Pacific'. Food and Nutrition Bulletin 22(4):1-58.

44. Popkin B (1994) The nutrition transition in low-income countries: An emerging crisis. Nutrition Reviews 52(9): 285-298.

45. Popkin BM (2006) Global nutrition dynamics: the world is shifting rapidly toward a diet linked with non-communicable diseases. American Journal of Clinical Nutrition 84:289-98.

46. Riaño E (2003) Organizando su espacio, construyendo su territorio: transformaciones de los asentamientos Ticuna en la ribera del Amazonas Colombiano. Universidad Nacional de Colombia, Bogotá D.C.

47. Ruel MT (2003) Operationalizing dietary diversity: A review of measurement issues and research priorities. Journal of Nutrition 133:3911S-3926S

48. Rushton J, Viscarra R, Viscarra C, Basset F, Baptista R, Brown D (2005) How important is bushmeat consumption in South America: now and in the future?. Odi Wildlife Policy Briefing 1. URL: http://www.odi.org.uk/resources/download/2418.pdf

49. Savy M, Martin-Prevel Y, Sawadogo P, Kameli Y, Delpeuch F (2005) Use of variety/diversity scores for diet quality measurement: relation with nutritional status of women in a rural area in Burkina Faso. European Journal of Clinical Nutrition 59:703-716.

50. Silva AL, Begossi A (2009) Biodiversity, food consumption and ecological niche dimension: a study case of the riverine populations from the Rio Negro, Amazonia, Brazil. Environment, Development and Sustainability11:489-507.

51. Silva H, Padez C (2010) Body size and obesity patterns in Caboclo populations from Pará, Amazonia, Brazil. Annals of Human Biology 37:217-229.

52. Silva CO, Andrade GF, Dantas MIS, Costa NMB, Peluzio MCG, Fontes EAF, Martino HSD (2010) Influência do processamento na qualidade protéica dead novos cultivares de soja destinados à alimentaçâo humana. Revista de Nutrição 23(3):389-397.

53. Sneyd LQ, Legwegoh A, Frase EDG (2013) Food riots: Media perspectives on the causes of food protest in Africa. Food Security 5:485-497.

54. Steyn NP, Nel JH, Nantel G, Kennedy G, Labadarios D (2006) Food variety and dietary diversity scores in children: are they good indicators of dietary adequacy? Public Health Nutrition 9(5): 644650.

55. Stoian D (2003) Making the best of two worlds: rural and periurban livelihood options sustained by non-timber forest products from the Bolivian Amazon. Paper presented at The International Conference on Rural Livelihoods, Forests and Biodiversity 19-23 May 2003, Bonn, Germany.

56. Suárez-Mutis $M$, Mora C, Pérez L, Peiter $P(2010)$ Interacciones transfronterizas y salud en la frontera Brasil-Colombia-Perú. Revista Mundo Amazónico 1: 243-266.

57. Tagle MA (1988) Cambios en los patrones de consume alimentario en América Latina. Archivos Latinoamericanos de Nutrición 38:758-765.

58. Tavares EF, Vieira-Filho FPB, Sanudo AA, Gimeno SG, Franco LJ (2003) Metabolic profile and cardiovascular risk patterns of and Indian tribe living in the Amazon Region of Brazil. Human Biology 75:31-46. 
59. Termote C, Bwama Meyi M, Dhed'a Djailo B, Huybregts L, Lachat $C$, Kolsteren P, van Damme P (2012) A biodiverse rich environment does not contribute to a better diet: a case study from DR Congo. PloS ONE 7(1): e30533.

60. Torheim LE, Ouattara F, Diarra MM, Thiam FD, Barikmo I, Hatloy A, Oshaug A (2004) Nutrient adequacy and dietary diversity in rural Mali: association and determinants. European Journal of Clinical Nutrition 58(4):594-604.

61. van Vliet N, Nebesse C, Nasi R (2014a) Bushmeat consumption among rural and urban children from Province Orientale, Democratic Republic of Congo. Oryx 49(1): 165-174.

62. van Vliet N, Quiceno-Mesa MP, Cruz-Antia D, Neves de Aquino LJ, Moreno J, and Nasi R (2014b) The uncovered volumes of bushmeat commercialized in the Amazonian trifrontier between Colombia, Peru \& Brazil. Ethnobiology and Conservation 3: 1-11.

63. Weinberger K, Swai I (2006) Consumption of traditional vegetables in central and northeastern Tanzania. Ecology of Food and Nutrition 45(2):87-103.

64. Welch J, Ferreira A, Santos R, Gugelmin S, Werneck G, Coimbra $C$ (2009) Nutrition transition, socioeconomic differentiation, and gender among adult Xavante Indians, Brazilian Amazon. Human Ecology 37(1):13-26.

65. Wunder S, Börner J, Shively G, Wyman M (2014) Safety nets, gap filling and forests: a global-comparative perspective. World Development64(S1): S29-S42. doi:10.1016/j.worlddev.2014.03.005.

66. Zarate C (2008) Fronteras en la globalización: localidad, biodiversidad y comercio en la Amazonia. Observatorio Andino v. 1. Universidad Javeriana. Fundación Konrad Adenauer. ISBN: 978-958-98301-1-6 